DOI: $10.20472 /$ TEC.2019.008.025

TSWAKAE SEBOTSA

Self-Directed Learning, North-West University (NWU), South Africa

JOSEF DE BEER

Self-Directed Learning, North-West University (NWU), South Africa

JEANNE KRIEK

University of South Africa (UNISA), Pretoria, South Africa

\title{
SELF-DIRECTED LEARNING AND TEACHER PROFESSIONAL DEVELOPMENT: AN ADAPTED PROFILE OF IMPLEMENTATION
}

\begin{abstract}
:
The leitmotiv of this paper is an appreciative inquiry of the Rogan and Grayson (2003) Profile of Implementation heuristic, which has the potential to guide teacher professional development programmes, and also record a teacher's growth and development during such interventions. The research question that guides this paper is, 'what are the affordances and limitations of Rogan and Grayson's (2003) Profile of Implementation to guide teacher professional development?' To this end, we structure the paper according to the four dimensions included in the Rogan and Grayson heuristic, namely (a) classroom interaction, (b) practical work, (c) science and society, and (d) assessment. The research context is a teacher professional development programme facilitated by the North-West University in Potchefstroom, South Africa, in which ten science teachers participated. In this research we identified the need to map teachers' progress in terms of their professional development. In the Rogan and Grayson heuristic, teachers are plotted in each of the four dimensions (classroom interaction, practical work, science-and-society perspectives, and assessment) in one of four levels (with level 1 indicating basic compliance, and level 4 mastery. However, we adopted Petersen's interpretation of the heuristic, which also provides for a level 0 , indicating non-compliance). In the paper we focus on research data on teachers' classroom interaction, their ability to facilitate practical laboratory work based on the tenets of science, their ability to effectively contextualize science, and to engage in meaningful assessment. We also show how the professional development programme attempted to assist teachers' learning and professional development in each of these four dimensions. We critique the Profile of Implementation based on the absence of self-directed learning (SDL) in it. Self-directed learning describes a process by which individuals take the initiative, with or without the assistance of others, in diagnosing their learning needs, formulating learning goals, identifying human and material resources for learning, choosing and implementing appropriate learning strategies, and evaluating learning outcomes. A particular contribution of this paper is the suggestion that a fifth dimension should be added, namely self-directed learning. The proposed fifth dimension sees self-directed learning as a sine qua non for development in the other four dimensions. Such a focus on SDL could arguably assist the teacher in a quicker transition from one level to the next.
\end{abstract}

\section{Keywords:}

Teacher professional development, Classroom interaction, Practical work, Science and society, Assessment, Self-directed learning, Profile of Implementation, Nature of Science and Nature of Indigenous Knowledge 
JEL Classification: $123,124,121$ 


\section{Introduction}

South African education is one of the biggest recipients of government funding. In 2012, education comprised 20.6 percent of government expenditure (World Bank, 2014). The country spends $5.4 \%$ of its GDP on education, and this is high by comparable standards (Taylor, Fleisch and Shindler, 2019). Vast spending should be tantamount to good grades, skills, and job opportunities and a high level of education should ensure a high level of employment (Bhorat, 2004.) However, currently, most of the South African learners who have secondary education and equivalent are not employed in formal sectors (Odhiambo, 2015), and a high unemployment growth rate exists amongst South African graduates (Bhorat, 2004). "The youth unemployment rate in South Africa is staggering, and increased from $54.7 \%$ in the fourth quarter of 2018 to $55.2 \%$ in the first quarter of 2019" (Stats SA, 2019 and Mail \& Guardian, 2019). The Statistics South Africa recapitulate that youth between the ages of 15-34 years are hit the hardest by unemployment (Stats SA, 2019). One of the reasons for this unemployment might be that they do not have the necessary skills and knowledge expected in a complex 21st century. The above insights defy Keynesian theory on government expenditures and economic growth as this theory states that an increase in government expenditure leads to an increase in economic growth via an expansionary fiscal policy. Unfortunately, this is not the case in the South African context at the moment.

The International Monetary Fund (IMF) reasons that South Africa's weak education system is partly to be blamed for sluggish economic growth (Buisinesstech, 2019). Taylor, Fleisch and Shindler (2019) redirect the above problem to learners who never acquired basic language and relevant mathematics skills at a primary school level. Spaull (2015) is of the view that low-quality education becomes a poverty trap for most South Africans. In South Africa, science and mathematics, as well as teacher education, are in a precarious state. For instance, South Africa performs dismally in almost all international benchmark tests (Buisinesstech, 2019). Mentz and De Beer (2019) are of the view that mathematics and science teaching and learning are a sine qua non for economic growth. For example, poor education probably contributes to the South African unemployment rate and 126000 job losses in the first quarter of 2019 (Stats SA, 2019). Another daunting aspect is that the South African economy is growing below $1 \%$ (Stats SA, 2019). Therefore, it is apparent that our education system should invest in teacher education that would meet the minimum requirement to facilitate the development of 21 st-century skills in the young generation. This directive has the affordances of equipping students with self-directed learning skills that will assist them in solving problems in a complex 21 st century.

Currently, South Africa faces multidimensional challenges concerning teacher competencies. To this effect, Rogan and Grayson (2003), developed a Profile of Implementation heuristic and identified four domains that should be considered in teacher professional development. The domains are (a) classroom interaction (which includes teachers' pedagogical content knowledge and pedagogical orientation), (b) facilitation of practical work (which brings problems related to the views of teachers on the nature of science, and the lack of resources in some classrooms to execute practical work to the fore), (c) science-and-society perspectives, and contextualizing science (the "western" curriculum does not necessarily address the affective domain, and does 
not always create interest in science amongst diverse South African learners), and (d) the assessment practices of teachers. There are four levels suggested by Rogan and Grayson, which varies from 1 to 4 , where the levels progress from teacher-centred demonstrations (level 1) to open-ended learner-centred investigations (level 4). (However, in this paper we adopt the adapted Profile with five levels $(0-4)$ as suggested by Petersen and De Beer (2012)). The leitmotiv of this paper is an appreciative inquiry but also critical take on the Rogan and Grayson (2003) Profile of Implementation heuristic, which has the potential to guide teacher professional development programmes, which could potentially address the perennial concerns discussed earlier. It should be made unequivocal from the start that this paper reports preliminary findings of the ongoing design-based research (DBR). The research question that guides this paper is: What are the affordances and limitations of Rogan and Grayson's (2003) Profile of Implementation to guide teachers' professional development?

\section{Problem statement: Perennial concerns in South African science education}

The recurrent problems with science education are highlighted, according to the four dimensions in the Rogan and Grayson (2003) construct.

\subsection{Classroom interaction}

Positive classroom interaction should promote robust science dialogues that promote cognitive dissonance (Festinger, 1962) amongst learners and teachers. Learners should engage and challenge science constructs rather than listen to science as if it is a novel. However, the status of mathematics and science education in South Africa is a cause for concern (Kriek and Grayson, 2009; Sebotsa, De Beer, and Kriek, 2018). Most of these concerns are often directed to teachers. Research done by the Centre for the Development Enterprise (CDE, 2011) states that one of the many struggles facing South African classrooms is poorly trained teachers. According to CDE (2011: 7), "South Africa has some of the least-knowledgeable primary school mathematics teachers in sub-Saharan Africa. Many of these mathematics teachers, especially those that serve poor and rural communities, have below-basic levels of content knowledge. In many instances, these teachers cannot answer questions their learners are required to answer according to the curriculum". A similar comparison is made in the intermediate phase. Venkat \& Spaull (2015) have shown that $17 \%$ of grade 6 learners in South Africa were taught by mathematics teachers who had content knowledge below grade 4 or 5 levels and $62 \%$ of grade 6 learners were taught by mathematics teachers who had a grade 4 or 5 level of content knowledge. The above results imply that $79 \%$ of the grade 6 mathematics teachers in South Africa are at least a grade below the required standard of teaching.

The national education department admitted that 5,139 teachers are either unqualified or underqualified (Times Live, 2019). In the McKinsey study (2007), it was highlighted that no schooling system could rise above the limits imposed by the quality of its teachers. If one has to extrapolate Venkat \& Spaull's (2015) findings above, it will not be peculiar to notice that the further education and training (FET) band is also characterized by poor performance. Ramnarain and Schuster (2014) indicate that most township FET Physical Sciences teachers have poor pedagogical orientations. For instance, many teachers still read from the textbook, and 'chalk-and-talk' approaches dominate many science classrooms (Ramnarain \& De Beer, 2012). We are of the view that such a pedagogy (reading from a textbook and chalk-and-talk approaches) center-stage 
parrot-like learning, which does not necessarily promote inquiry minds and could corrode positive classroom interaction. Learners in such classrooms possibly do not develop the communication skills needed in the workplace. Therefore, it does become imperative to address teacher education at the grassroots level if we are serious about unlocking nascent scholarship, inquisitive and skilled scientific learners. To possibly address this problem, well designed professional development interventions are imperative.

\subsection{Practical work}

Jenkins (1999) is of the view that it is only through practical laboratory work that learners get real experience about the natural world. To engage effectively in practical laboratory work, learners need skill capital. Despite the emphasis on scientific skills in the official school curriculum, little of these skills often materialise in the classroom. Learners often do not develop good understandings of the tenets of science, as they do not engage in the processes of science (Motambatamba, 2018). A reason for this is that science teachers in South Africa often do not have nuanced views of the nature of science themselves (Motambatamba, 2018). Inquiries in the school laboratory are more the exception than the norm. Several authors list the lack of resources (such as suitably furnished laboratories), and information and communication technologies (ICT's) as reasons for the poor science and mathematics performance in South Africa (Mullis, Martin, Foy \& Arora, 2012).

Moreover, Sebotsa, De Beer, and Kriek (2018) are of the opinion that teachers lack agency, and are often not able to improvise in under-resourced classroom laboratories. Some schools are severely under-resourced, while some have no resources at all (ibid). The National Education Infrastructure Management System (NEIMS) statistics reaffirm this. In Table 1 below, we see that the percentage of ordinary schools in South Africa without laboratories ranges from $60 \%$ to $94 \%$ in different provinces. While real experimentation with conventional laboratory apparatus and equipment is desired, most schools in rural South Africa like other developing countries face challenges of inadequate resources, particularly financial resources for acquiring apparatus and materials for imparting practical and efficient science education.

Table 1: Department of Education laboratories summary grid for ordinary schools

\begin{tabular}{|l|l|l|l|l|l|l|l|}
\hline Province & $\begin{array}{l}\text { Number } \\
\text { of } \\
\text { schools }\end{array}$ & $\begin{array}{l}\text { Number } \\
\text { of } \\
\text { schools } \\
\text { with } \\
\text { laboratory }\end{array}$ & $\begin{array}{l}\text { \% of } \\
\text { schools } \\
\text { With } \\
\text { laboratory }\end{array}$ & $\begin{array}{l}\text { Laboratory } \\
\text { Stocked }\end{array}$ & $\begin{array}{l}\% \\
\text { Stocked }\end{array}$ & $\begin{array}{l}\text { Schools } \\
\text { without } \\
\text { laboratory }\end{array}$ & $\begin{array}{l}\text { \% } \\
\text { schools } \\
\text { Without } \\
\text { laboratory }\end{array}$ \\
\hline $\begin{array}{l}\text { Eastern } \\
\text { Cape }\end{array}$ & 5,676 & 493 & 9 & 110 & 2 & 5,183 & 91 \\
\hline Free State & 1,615 & 337 & 21 & 103 & 6 & 1,278 & 79 \\
\hline Gauteng & 2,031 & 813 & 40 & 287 & 14 & 1,218 & 60 \\
\hline
\end{tabular}




\begin{tabular}{|l|l|l|l|l|l|l|l|}
\hline $\begin{array}{l}\text { KwaZulu- } \\
\text { Natal }\end{array}$ & 5,931 & 719 & 12 & 221 & 4 & 5,212 & 88 \\
\hline Limpopo & 3,923 & 235 & 6 & 59 & 2 & 3,688 & 94 \\
\hline Mpumalanga & 1,868 & 213 & 11 & 53 & 3 & 1,655 & 89 \\
\hline North West & 1,674 & 269 & 16 & 72 & 4 & 1,405 & 84 \\
\hline $\begin{array}{l}\text { Northern } \\
\text { Cape }\end{array}$ & 611 & 180 & 29 & 67 & 11 & 4,31 & 71 \\
\hline $\begin{array}{l}\text { Western } \\
\text { Cape }\end{array}$ & 1,464 & 513 & 35 & 259 & 18 & 9,51 & 65 \\
\hline TOTAL & 24,793 & 3,772 & 15 & 1,231 & 5 & 21,021 & 85 \\
\hline
\end{tabular}

Source: National Education Infrastructure Management System (NEIMS), May, 2011:no page number)

The authors of his paper are of the view that skills such as inquiry learning and self-directed learning should be emphasised during professional development interventions and teacher education.

\subsection{Science and society}

According to Gibbons (1999:15), "reliable knowledge will only be categorised as socially robust if society sees the process of knowledge production as transparent and participative". According to him, science should be perceived as relevant to society, and everyday life of people. Indigenous knowledge holds affordances to make science relevant for learners, and to show them how science plays a role in everyday life. The United Nations defines indigenous knowledge as the understanding, skills and way of life developed by society with reference to their interaction with their natural surroundings. Integrating indigenous knowledge in the current education practices holds affordances to benefit both the non-indigenous and indigenous learners (Munroe et al., 2013). This idea is encapsulated in the $21^{\text {st }}$-century skills needed for a modern curriculum; examples of such skills include creativity, collaboration, problem-solving, innovation, inquiry and multicultural literacy (ibid).

On the other hand, the South African science curriculum had in the past failed to emphasise a participative stance between science and society (Cronje, 2015). The field of curriculum design and implementation in South Africa has been in constant flux since its inception in the early 20th century. This results in a continued shift and change (Breault \& Marshall, 2010). The South African education system and teachers are still experiencing 'curriculum fatigue'. None of these curriculum changes have resulted in the desired change in the classroom, such as including indigenous knowledge (IK) as prescribed in the South African curriculum (Cronje, 2015). For instance, the curriculum states that learners should understand and appreciate the use of natural sciences and indigenous knowledge in society and the environment (specific aim 3 of the CAPS). 
Failure to do so results in learners not being able to relate to the curriculum (Cronje, 2015), as the curriculum does not address the affective domain, and does not enhance learner motivation in terms of becoming life-long learners of science.

In the light of the above, movements (protests) such as \#ScienceMustFall (Jansen 2017:155), \#RhodesMustFall and \#FeesMustFall campaigns plagued education since 2015, when students echoed dissatisfaction with the current "western curriculum". These movements resulted in the shut-down of many universities in South Africa. The students during these protests demanded the "decolonisation" and "transformation" of higher education institutions. The view was that the western curriculum is based on Gibbons's mode one learning. Mode 1 learning focuses on knowledge production and one way of knowing (Gibbons, 2000). This dissatisfaction with the curriculum highlights the importance of contextualising the science curriculum (Cronje, 2015) to achieve mode two (2) learning (Gibbons, 2000). Gibbons refers to mode 2 learning as contextsensitive science. In mode 2 learning, people and communities talk back to science and create a robust discourse. Studies by Mothwa (2011) and De Beer (2016) show that many South African teachers are not able to contextualise the curriculum well, and they do not have the pedagogical content knowledge (PCK) to infuse indigenous knowledge in curriculum themes. One reason for this unfortunate state of affairs is that science teachers were not trained in such epistemological border-crossing and could possibly be addressed by design-based professional development interventions.

\subsection{Assessment}

Many South African classrooms are subjugated to poor learner's assessment (Harrold et al., 2002). Amongst many reasons is the systemic pressure coming from the Department of Education (DoE), principals, parents (for better learner results) and underqualified teachers (Sebotsa, De Beer \& Kriek, 2018). For instance, many teachers teach to the test/ examination and use rote learning to ensure good results. Assessment often only focuses on lower levels in Bloom's taxonomy of the cognitive domain. Authors such as De Beer and Ramnarain (2012) lament chalk-and-talk approaches, which refer to rote learning, and how such approaches often lead to poor assessment practices. Rote learning has been associated with reduced educational outcomes. It is not surprising that $50 \%$ of learners have dropped out of school by the time of their matric year (Spaull, 2015). Hence, according to Spaull (2015), poor assessment cast doubt on the ability of the South African education system to convey the skills, knowledge, and values that learners need to become full members of society and promotes social mobility.

Effective assessment practices should be emphasized during teacher professional development programmes (Cooke and Gorman, 2006). To ensure that assessment is successful, learners should be placed at the centre of assessment. This will require learners to understand the methods of assessment and to take the initiative in different ways of assessing with the guidance of a teacher. Hence a teacher is required to be self-directed as well in order to facilitate learnercentred assessment.

After considering the heuristic of Rogan and Grayson's profile of implementation, a missing link was identified, namely the need for teachers to become self-directed in order to improve the four domains above. 


\subsection{The missing link in South African school classrooms: Self-Directed Learning}

Functioning effectively in the 21st-century society requires one to possess adequate social capital, and also self-directed learning (SDL) (Bourdieu, 1986). It is not surprising that SDL is now considered strongly in the context of most higher education (Cheng et, al, 2010). If learner motivation and interpersonal communication, which forms elements of SDL, is considered, one quickly concludes that these elements are "silent" in most South African township schools. These elements are silent since most classrooms rely predominantly on transmission mode teaching and learning. A possible reason could be that teachers themselves are often not self-directed, and therefore, do not enhance self-directed learning in their classrooms. Self-directed learning in its broadest meaning describes "a process by which individuals take the initiative, with or without the assistance of others, in diagnosing their learning needs, formulating learning goals, identifying human and material resources for learning, choosing and implementing appropriate learning strategies, and evaluating outcomes" (Knowles,1975:19). Teachers need to be self-directed learners who could identify learning goals for themselves and manage their learning effectively. Self-directed learning is not emphasized enough (in our view) in Rogan and Grayson's Profile of Implementation.

The research question that guides this paper is: What are the affordances and limitations of Rogan and Grayson's (2003) Profile of Implementation to guide teachers' professional development? A particular contribution of this paper is the suggestion that a fifth dimension should be added, namely self-directed learning.

\section{Research methods}

This mixed-methods, design-based research focused on ten natural science teachers' involvement in a professional development intervention over two years, which included a twodays short learning programme (SLP). During the intervention, various aspects such as inquiryand cooperative learning approaches, content knowledge in specific topics (e.g. optics), indigenous knowledge and the nature of science were addressed. For example, the teachers were provided with the opportunity to learn more about DNA technology, during a two-day workshop at the African Centre for DNA Barcoding. Quantitative data included the self-rating instrument to measure self-directed learning, developed by Cheng, Kuo, Lin and Lee-Hsieh (2010). Qualitative data included individual- and focus group interviews with the teachers, classroom observations using the Reformed Teaching Observation Protocol (RTOP) instrument developed by Sawada et al., (2002). The teachers completed questionnaires on the views of science (VNOS) and the views of indigenous knowledge (VNOIK). The VNOS instrument was developed by Abd-El-Khalick et al., (1998), and the VNOIK instrument was developed by Cronje et al., (2015). This VNOIK instrument was developed based on the structure of the VNOS instrument. We coded the data using Saldana's (2016) coding technique to cluster codes into categories and to distil a number of themes. These themes are presented within the 'Profile of Implementation' framework of Rogan and Grayson (2003). Apart from complying with the ethics required by the University, additional permission was asked and granted by all teachers to use their pictures in publications. 


\section{Practical solutions that form the vortex of our Design-Based Research in the intervention: moving towards a revised Profile of Implementation}

During the past five years of this design-based research, and specifically the two-year lifespan of this specific research, we have identified several limitations but also developed several potential solutions to the problems discussed above. We would now like to highlight some of these limitations and solutions and also highlight the role of self-directed learning in moving science education forward.

\subsection{Classroom interaction}

During the pre-intervention classroom observations, most teachers used textbooks and chalkand-talk approaches to teach science lessons. What is of concern is that inquiry activities were not evident during the lessons, and learner engagement was not inquiry-based. Pre-and posttests on optics were administered, and it was found that in the pre-test, only one educator managed to obtain more than $50 \%$, and the rest of the teachers obtained marks that were below a $50 \%$ pass mark. The above results confirm what was found by CDE (2011) and is quite alarming, given the fact that the test covered Grade 8 optics constructs- elementary work that any teacher should know by heart. One of the teachers scored 2 out of 35 marks (6\%). Another concern that manifested during the pre-intervention classroom observations was that most teachers did not engage in inquiry-based learning, and instead, transmission mode and authoritative classroom management dominated the lessons.

To provide teachers with assistance, we first suggest that teacher development should be based on teachers own needs (Sebotsa, De Beer and Kriek, 2018). This opportunity should be provided in a systemic and longitudinal teacher development programme within a well-established community of practice (CoP), with the assistance of "keystone" species (Pretorius, 2015 and Sebotsa, De Beer and Kriek, 2018). A "keystone" refers to an expert who can coach and provide assistance to the members of the community of practice (CoP). Therefore, during the intervention for these specific teachers, the emphasis was placed on (a) improving teachers' PCK related to problematic curriculum themes such as optics; (b) promoting learner-centred approaches such as cooperative learning and problem-based learning approaches, and (c) providing teachers with more nuanced understandings of indigenous knowledge. After the intervention, the teacher who obtained $6 \%$ in the pre-intervention optics test, passed the post-test with a mark of $54 \%$. In the post-test, seven teachers who participated (in this specific session) saw an average increase of $21 \%$.

\subsection{Practical work}

Limitations identified in practical work is under-resourced laboratories or lack thereof and teachers' deficiency in content knowledge (Sebotsa, De Beer and Kriek, 2018). Another concern is that teachers struggle to improvise by using inexpensive equipment, also referred to as 'shoestring science'. Teachers need to be trained to be agents of change and be capacitated with skills to use "science-on-a-shoestring" approaches in under-resourced classrooms. "Science-ona-shoestring" experiments (or, 'frugal science', according to Jackson, De Beer \& White, 2018) are inexpensive and could achieve the same level of objectives as in the case of using expensive apparatus, and possibly it might provide learners with a better understanding of the tenets of 
nature of science. It could also guide learners in following inquiry learning approaches. The effect of computer simulations compared to the use of traditional equipment was investigated.

\subsubsection{Enhancing "Science-on-a-shoestring" approaches}

In the 'Teachers without borders' project, teachers were provided with foldscopes microscopes, which cost one US dollar. This simple microscope makes inquiry learning in the rural classroom possible. For instance, learners can engage in enquiry learning activities, where they- for example- test water quality in water sources in the community, by looking at levels of eutrophication (polluted water will host different micro-organisms, to 'clean' water). Figure 1 provides a glimpse of the foldscope-microscope activity that teachers engaged in.
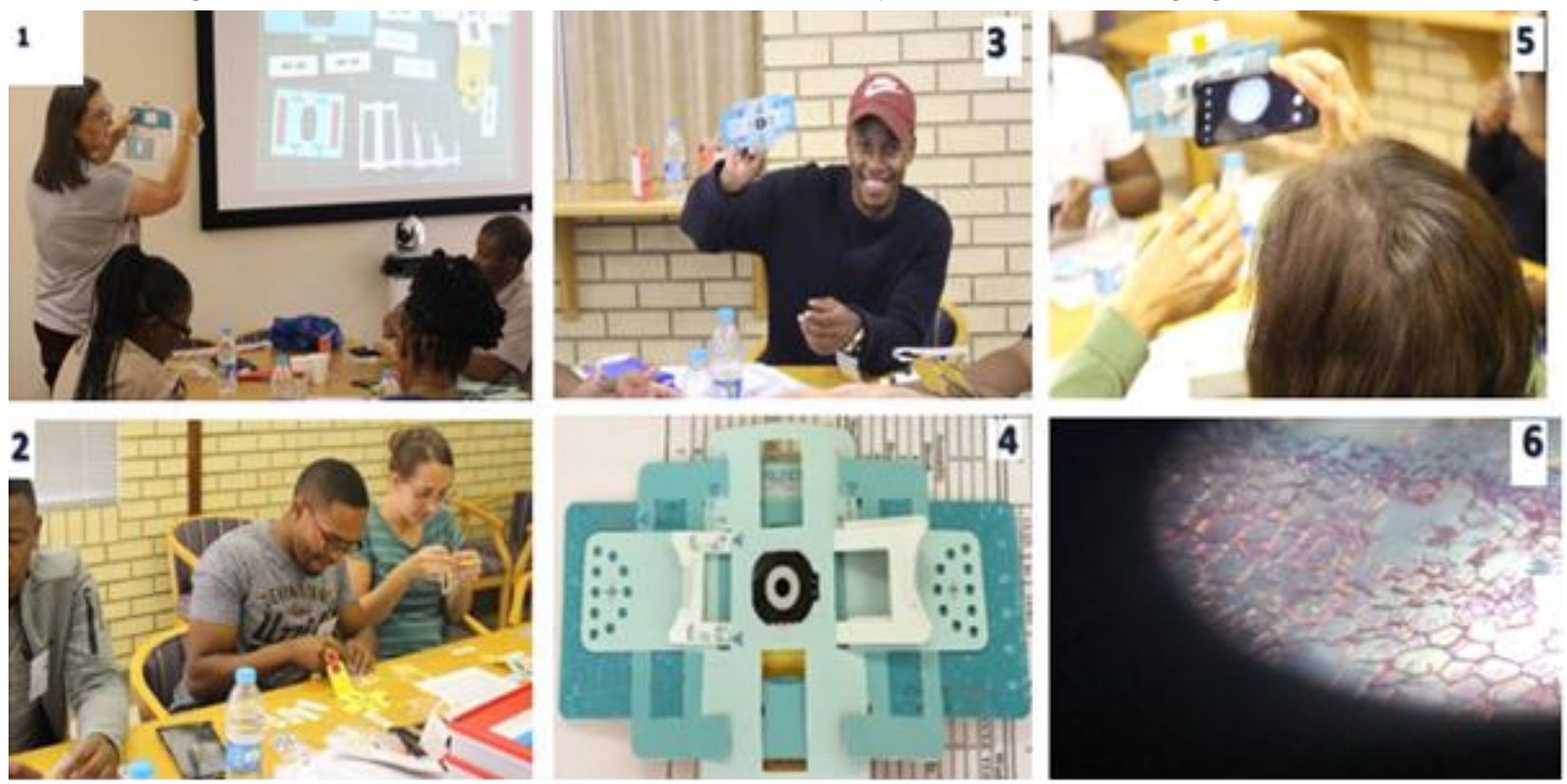

Figure 1: Science teachers engaging with foldscope microscopy with the assistance of "keystone" species (more capable peer)

In addition to the foldscope microscopes, the teachers were provided with the opportunity to build spectrometers, using cheap, recyclable materials, for the classroom, as can be seen in Figure 2 . 

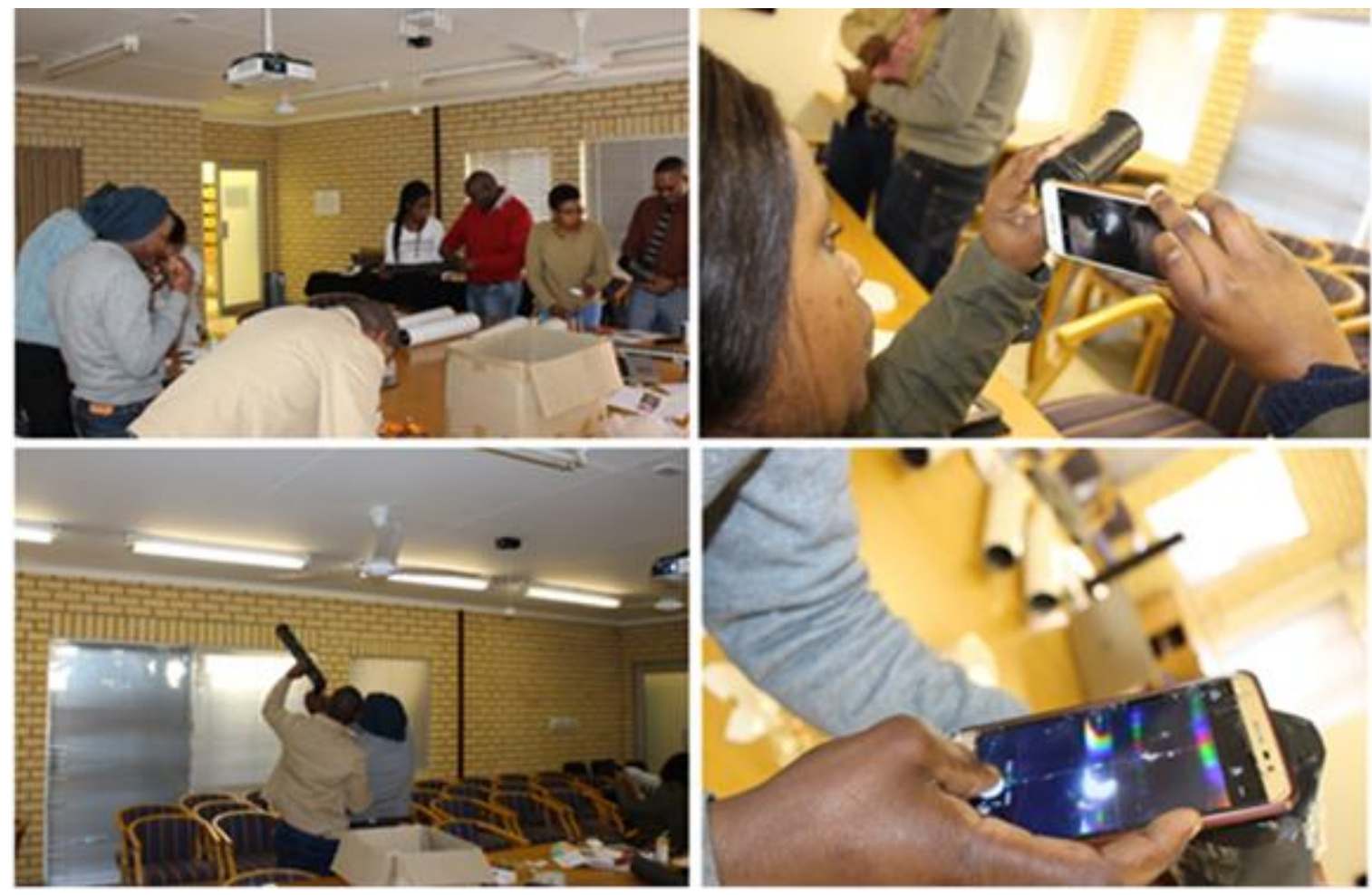

Figure 2: Teachers building spectroscopes using cheap materials

The researchers are currently busy observing different classrooms to verify if the teachers will design lessons in which learners can engage in inquiry activities with these spectroscopes. The authors are of the view that teachers should be engaged as agents of change during teacher development programmes and be guided on how to think outside the box in dealing with the challenges in under-resourced classrooms. Anecdotal evidence shows that teachers respond well to such frugal science approaches.

\subsubsection{Usage of PhET simulations in under-resourced classrooms: approaching the 21st-century classroom}

In a technological era, another aspect worth considering is that teachers must be encouraged and be trained to utilise ICT simulations, such as the physics educational technologies (PhET). Teaching utilising PhET interactive computer simulations (ICT's) could promote learning and the development of $21^{\text {st }}$-century skills. These skills include, amongst others, using computers and engaging learners to be self-directed in their learning (De Jong \& Van Joolingen et al., 1998). The Physics Education Technology (PhET) Project entails interactive computer simulations for teaching and learning different sciences. The PhET simulations demonstrate principles in physics, chemistry, biology, earth science, and mathematics (Podolefsky, Rehn and Perkins, 2013). These engaging, interactive simulations can be used in classrooms or under-resourced laboratories (ibid). The world in which learners find themselves today is fundamentally different from before; the expansion of information and communication technology is transforming the nature of learning (ibid). During the intervention, the teachers were equipped with tablets and were guided on how 
to use technologies in designing inquiry learning in their respective classrooms. The data used in this particular section is preliminary, and only artefacts were used. The researchers are in the second phase of classroom observation to record the affordances of PhET simulations in the teachers' science classroom. Figure 3 below provides snippets of PhET optics activity that teachers engaged in. In the figure, teachers can be seen engaging in the PhET simulations. Teachers explain to each other how simulations and inquiry learning can be used in the classroom.

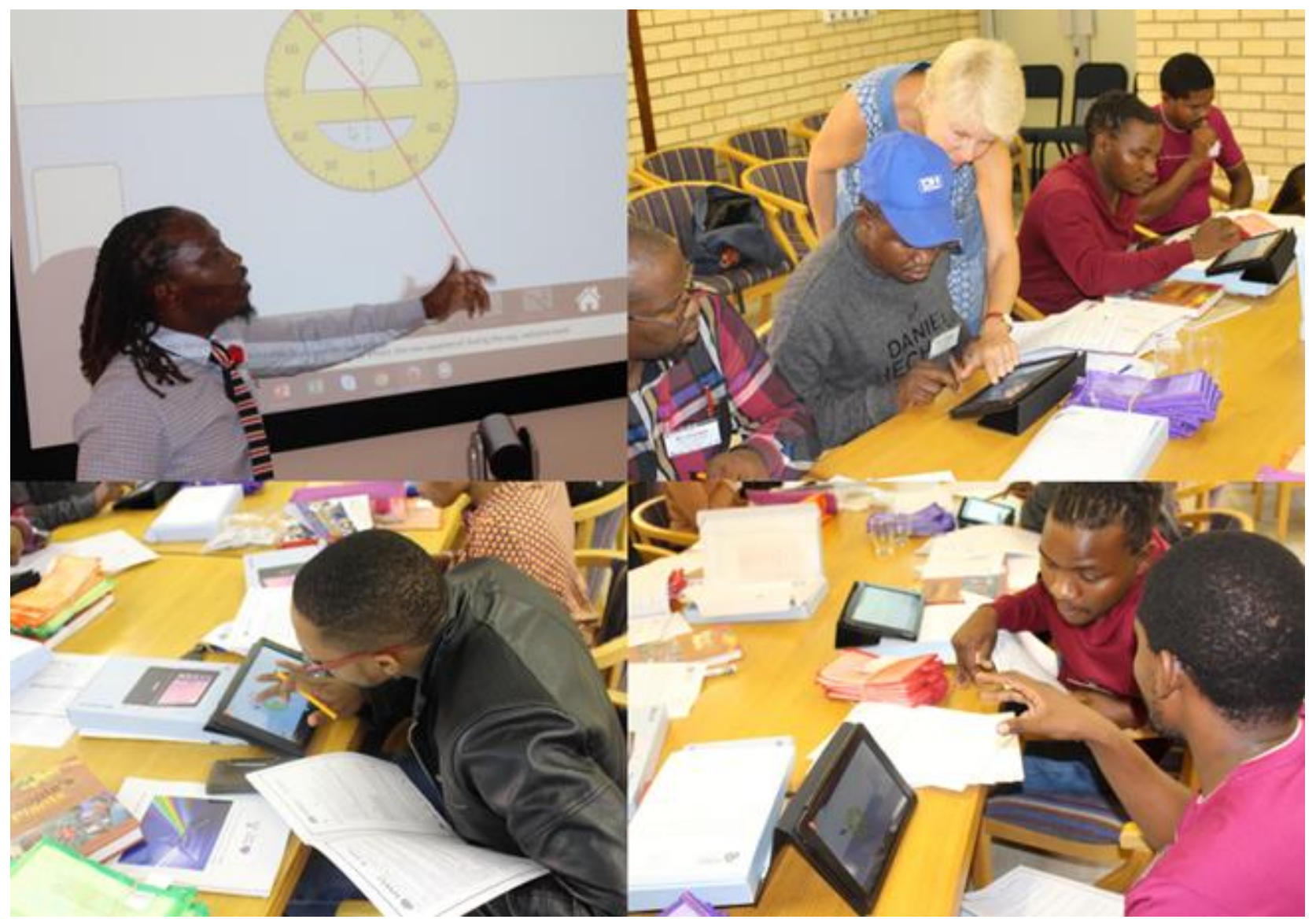

Figure 3: Teachers engaging using technologies with assistance from "keystone" species

\subsubsection{Immersing science teachers in authentic science activities in 'real' laboratories, with 'real' scientists}

Barber (2014) found that authentic science teacher experiences in laboratories with scientists improved science teaching. In our intervention, the participants went on a science excursion to the African Centre for DNA Barcoding at the University of Johannesburg (UJ), where the teachers engaged in authentic science with real scientists. Figure 4 below provides snippets of the excursion. The excursion aimed to emphasise the tenets of science and to equip the teachers with science process skills such as extracting DNA samples and engaging in Polymerase Chain Reactions (PCR).

In an interview, teachers made the following comments: 
Teacher A: "actually I found this very interesting, I did not know how to extract the DNA, I just saw it in the books, I did not know how they extract it or by engaging in the DNA, I saw how they extract the DNA, work on it until they get the final results".

Teacher A: "I never knew the analysis of the DNA actually, so now I can see that anything that is living, it can be plants or the animals; they have the DNA that we can classify them with it."

Teacher B: "For me it was informative. At first, I thought DNA was about checking paternity tests, but I did not know that it also goes to plants, and it goes further than that. I learned so many careers which my kids can go to one day and study. In university, I used to have friends who did BSc, but I did not know what exactly are they doing, and I always asked them, where are you going to work?, but today I know where you can work if you studied BSc, so I have learned quite a lot."

Teacher B: "it was fun, we learned new things. I can't wait to go back to the classroom and share the information which l've learned."

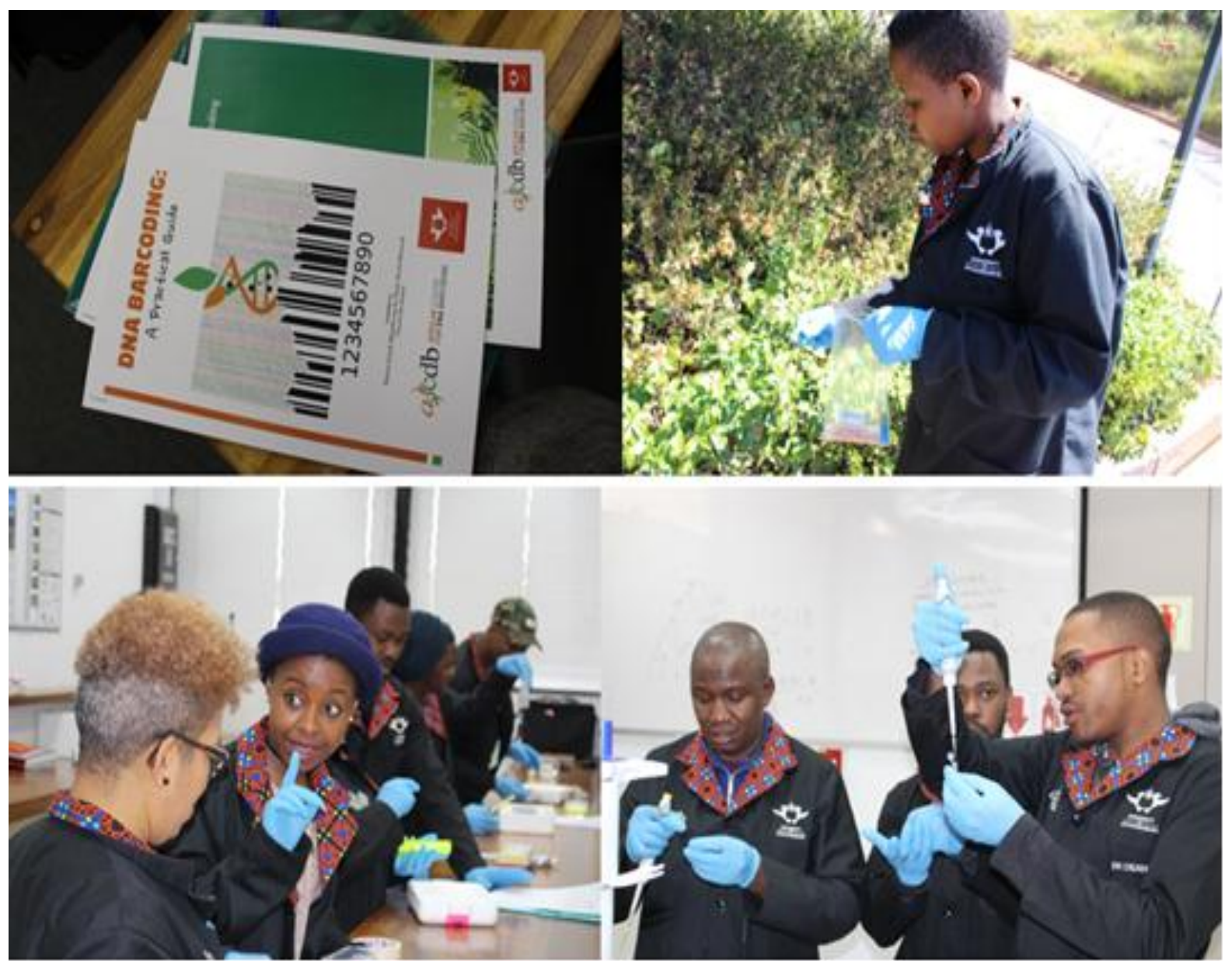

Figure 4: Teachers engaging in DNA barcoding

\subsection{Science and Society approaches}

By infusing indigenous knowledge (IK) into the curriculum, we might make science more exciting and more relevant for learners, and might improve performance (De Beer, 2016). According to 
Maxwell and Chahine (2013:67), active learning takes place in an atmosphere of a learner's "existing knowledge, background, and environment." They argue that indigenous learners exploring new concepts in their everyday settings enable them to construct and comprehended new knowledge. Dubinsky, Roehrig, and Varma (2013) show us that experiences with an emotional stamp are more likely to be committed to long-term memory.

Taylor and Cameron (2016) highlight and critique three epistemological perspectives that are inherent in the attempts at IK-Science integration as follows.

- An inclusive perspective where IK systems are regarded as part of science,

- Exclusive perspective in which indigenous knowledge systems (IKS) and science are treated as separated domains of knowledge. The exclusive scientific perspective advocates that science is limited to studying the material world and has nothing to say about the metaphysical aspect, which is a component of indigenous knowledge systems.

- IKS and science are viewed as intersecting domains, of overlapping strands; in other words, the focus should be on the shared tenets between western science and indigenous knowledge. In this paper, we advocate for the epistemological border-crossing between IK and science. We did not focus on the differences but the similarities between the two knowledges. The three perspectives are visually presented in Figure 5 below.

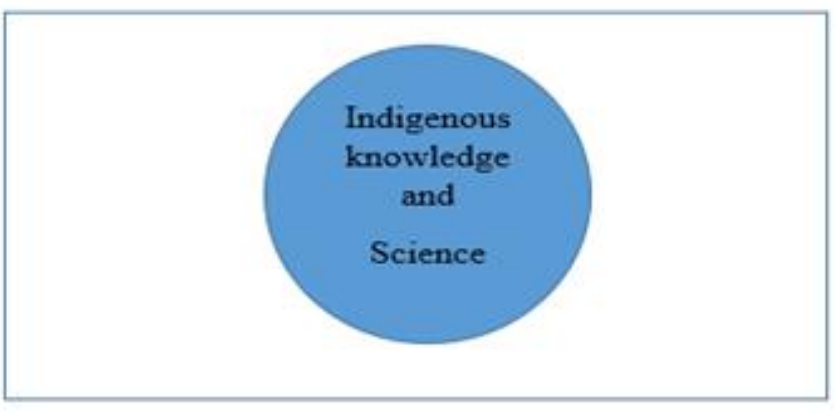

Inclusive perspective

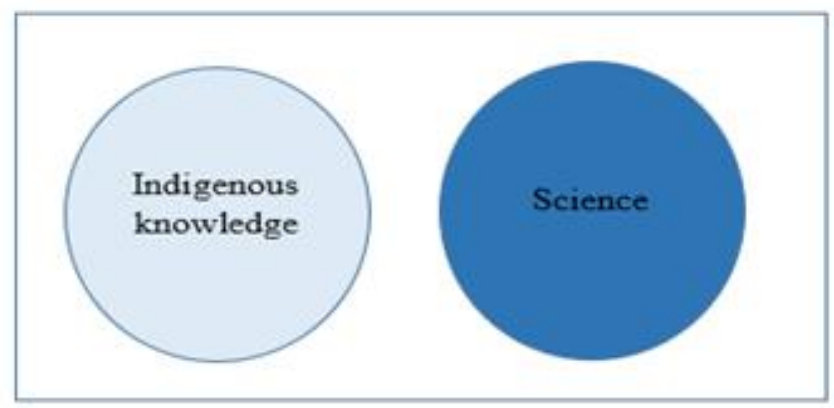

Exclusive perspective

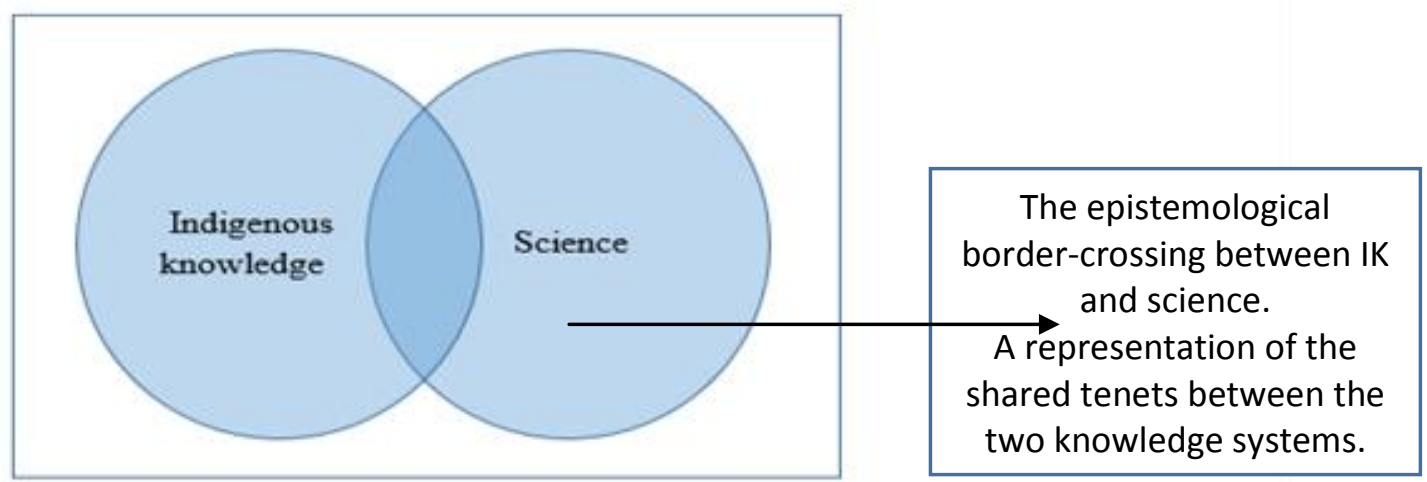

IKS and science are viewed as intersecting domains, of overlapping strands

Figure 5: The authors understanding of the epistemological differences in IK-Science integration (Based on Taylor \& Cameron, 2016; and Zinyeka, Onwu \& Braun, 2016) 
This paper argues the space between indigenous knowledge and science where the two knowledges are equally crucial in making sense of the world, and where the focus is on the shared tenets, rather than different tenets. Cronje (2015: 42) has shown that there are (despite several differences) many shared tenets when the nature of science and the nature of indigenous knowledge are compared. Both science and indigenous knowledge are empirical (although indigenous knowledge also has a metaphysical component). Both are tentative (and subject to change), both are inferential, both are creative, and both are social and cultural based. This approach could support science teaching that acknowledges students' knowledge and culturally based ways of thinking, which will almost certainly unlock the potential to make science more meaningful to learners (Cronje, 2015). This could result in learning science, which is not confusing but more interesting since learners might not struggle to relate the two knowledge systems. Western knowledge systems and indigenous knowledge systems need not be in conflict. Space where indigenous knowledge and Western ways of knowing connect and overlap can be understood as the 'cultural interface' (Nakata, 2002). This can be a contested space, but can also be a space where different ways of knowing work together synergistically (Nakata, 2010).

A practical example of the curriculum solutions offered to teachers during the "Teachers without borders" intervention is activity on soap-making. Teachers were shown how, through the chemistry of soap making, IK can be taught. In Africa, many plants have been used as natural sources of soap (Van Wyk and Gericke, 2018: 277). The latter scholars further reiterate that these plants contain a colossal amount of saponins that dissolve fat and oily substances insoluble in water. During the soap making the main ingredient becomes the animal fat and lye, which is customarily used to convert the animal fat or oil into soap. During this process, it should be made clear that a caustic alkali hydrolyses the fat. The combination of the hydrolysed fat and acoustic alkali result in the product of the soap and glycerol. The soap that is formed is the result of the potassium salt or the sodium of fatty acids. The chemical process of doing so is called saponification (Van Wyk and Gericke, 2018: 277).

The glycerol from the animal fat in the soap is commonly used as a moisturiser to protect the skin against the intense African sun rays. The soap making in the African context use plants instead of $\mathrm{NaOH}$ (ibid). Traditionally the indigenous people of Africa have used plants such as Helinus integrifolius and Noltea africana for bathing, as cleaning agents (detergents) and for washing clothes (Van Wyk and Gericke, 2018: 277). The plants above have the characteristics of producing a large quantity of foam when crushed and dissolved in water (Van Wyk and Gericke, 2018: 277). Currently, the soap-making practices are still prominent in rural areas of South Africa (ibid). It is the basis of such practices that the researchers advocate for the inclusion of indigenous knowledge in the Natural Sciences classroom. In Figure 7, it is shown how teachers during the SLP engage in soap making. 

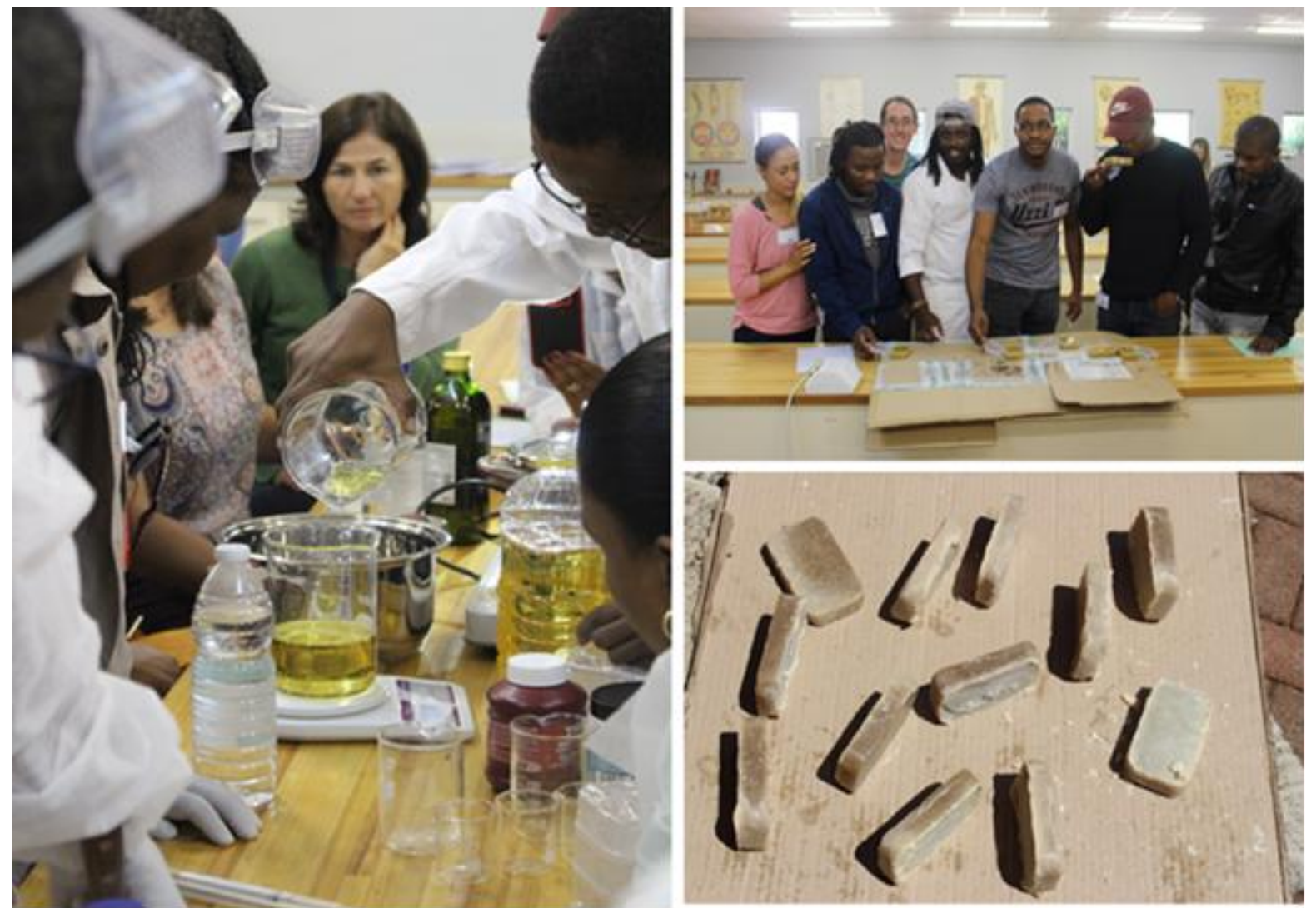

Figure 7: Teachers engaging as self-directed learners in the soap making

In the first cycle of 2018 of the design-based research (DBR) the pre- VNOIK questionnaire indicated that most teachers had uninformed or partially informed views on the nature of indigenous knowledge (Sebotsa, De Beer and Kriek, 2019). The data made it evident that teachers had naïve understandings of the tenets of indigenous knowledge. The post-intervention data show that teachers developed more nuanced understandings of indigenous knowledge, as a result of this intervention. The data below is not just for the ten teachers who formed part of the two-year intervention but includes the data for all teachers who participated in the two days SLP that formed part of the two year cycle intervention. This is shown in Table 2.

Table 2: Teachers views on indigenous knowledge

\begin{tabular}{|l|l|l|}
\hline View of participants & $\begin{array}{l}\text { Percentage in the pre- } \\
\text { questionnaire } \\
\text { intervention }\end{array}$ & $\begin{array}{l}\text { Percentage in the post- } \\
\text { questionnaire } \\
\text { intervention) }\end{array}$ \\
\hline Uninformed view & 4.5 & 0 \\
\hline Partially informed view & 78.5 & 54.5 \\
\hline Informed view & 17.0 & 45.5 \\
\hline
\end{tabular}


Based on the findings, we are of the view that a curriculum embedded in IK-Science will provide learners with context-sensitive science perspectives that address the affective domain, and that will promote self-directed learning in the classroom.

\subsection{Teachers' assessment practices}

Limitations identified in assessment practices is "chalk-and-talk" or rote learning approaches. Most teachers use rote learning with the rationale of making learners memorise the answers for tests and examination purposes, and this in no small extent is due to systemic pressure coming from the department of education and an overloaded curriculum. In addition, most teachers are not well equipped with different methods of assessments. There is a need for teachers to change their assessment practices. During the pre-intervention classroom observations, the researchers observed a similar trend of assessment practice among teachers, where most learners depend on the teachers for solutions. The teacher often stands in front of the learners and write the answers on the board with an inadequate explanation and solutions aimed at lower order cognition.

During the two years intervention, the teachers used the jigsaw (co-operative learning) method as a tool for peer assessment. The teachers used the jigsaw method to assess an intervention activity on visible light constructs. Zakaria and Iksak (2007) identify five benefits of cooperative learning, namely: 1) positive interdependence; 2) enhanced interaction; 3) individual accountability; 4) interpersonal and small-group skills; and 5) group processing. Peer assessment or group assessment can develop good assessment practices which are embedded in real-life activities or context.

During the interventions, the teachers further compiled portfolios of evidence on how they changed their assessment practices. The aim was to sensitise them to alternative and more creative forms of assessment. The portfolio that teachers had to develop addresses Natural Sciences themes on all levels of Bloom's taxonomy and are still to be analysed. During our later classroom observations, we started to notice improved assessment practices.

\subsection{Promoting Self-Directed Learning (SDL)}

A limitation in SDL literature is the focus on the individual, at the expense of the role of context in promoting self-directed learning. Some of the SDL mantras create the idea that self-directed learning is an individual quality only, not giving sufficient attention to the role of respectively the process, and the context.

To address this limitation, while conceptualising the ,Teachers without borders' project, we were reminded of the Person-Process-Context (PPC) model of Hiemstra and Brockett (2012). Below is the PPC model for self-directed learning. 


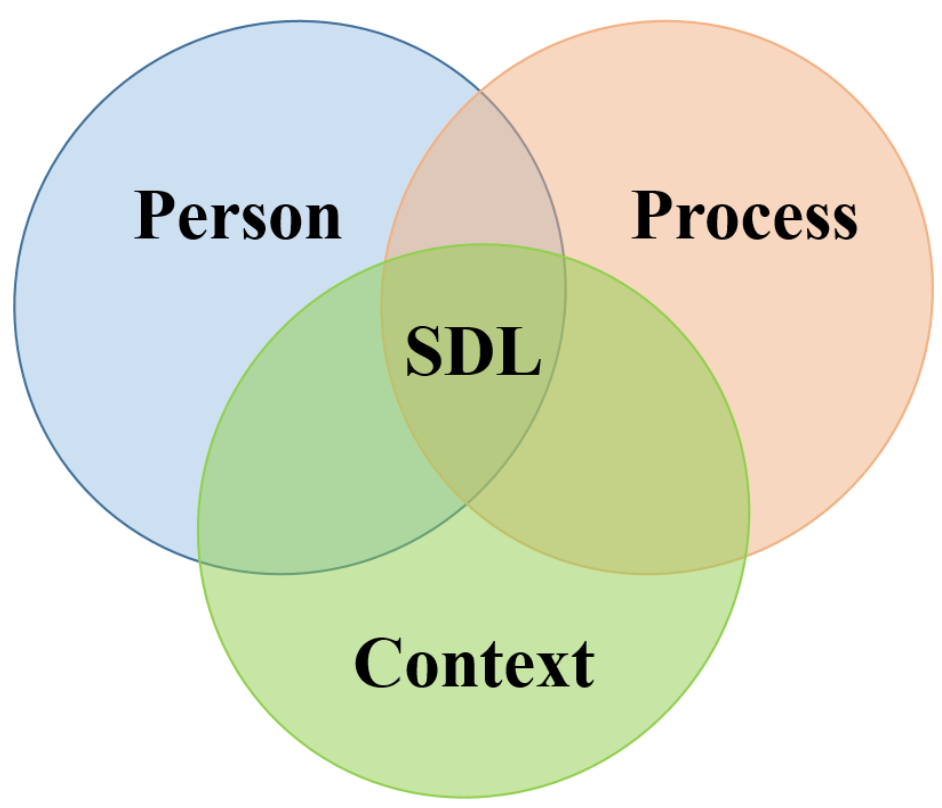

Figure 8: The Hiemstra and Brockett SDL model (2012: 158)

A learning context is created during the intervention and SLP that could enhance SDL. The context created center-stage cognitive dissonance (Festiger,1962). Teachers have to navigate the contested space between the natural sciences on the one hand, and indigenous knowledge on the other. This asks of them to face their own biases, alternative perspectives and naive understandings. It also requires the teacher to identify learning goals for themselves, identify resources to achieve their learning goals, and monitor their own progress. Teachers engage in cooperative learning and problem-based learning, and they are sensitised towards the role of engaging pedagogies (the process) in supporting SDL.

Teachers completed a pre-intervention Cheng (2010) questionnaire to determine their selfdirected learning skills. The post-intervention Cheng questionnaires will be completed by teachers in October 2019. However, anecdotal evidence exists of self-directed learning among the teachers. After the visit to the African Center for DNA Barcoding, several teachers identified goals for their own professional development (e.g. learning more about PCR, and laboratory protocols). Also, four of the science teachers have applied for registration in the Honours degree in 2020, fueled by the realisation that they need to invest in their own professional development.

\section{Revisiting Rogan and Grayson's (2003) Profile of Implementation: Self-directed learning as the Achilles heel?}

Rogan and Grayson's Profile of Implementation provides a useful heuristic to support teacher professional development. In this paper and in the "Teachers without borders" project, we support the recommendation of the latter authors that professional development of teachers is a long, continued process and not a "quick-fix". Rogan and Grayson recommend that implementation should consist of a series of small steps (thus a long-term process). Furthermore, the context of the school (teachers, learners, and environment) should be taken into account. The level of the teachers' pedagogical knowledge and experience should be considered when contextualising teacher professional development. 
Rogan and Grayson further suggest that professional development should be measured on four levels across each of the four domains (i.e. classroom interaction, science and practical work, science and society, and assessment). However, over the years, researchers such as Petersen (2011) critiqued the four levels (levels 1 to level 4) proposed by Rogan and Grayson. Petersen's critique was that a "level 1" in Rogan's model assumes basic compliance to minimum requirements. Teachers in Petersen's study did not make the grade in terms of a level 1, and for this reason, Petersen introduced a level zero (0) (Petersen \& De Beer 2012). We are of the opinion that the Profile of Implementation could be further strengthened by introducing another dimension, namely self-directed learning. In order to develop in terms of the four dimensions (e.g. move from a level 1 to a level 2, or from a level 3 to a level 4), also requires teachers to be selfdirected in their learning. SDL could be considered imperative to the construct of 'zone of feasible innovation' (ZFI). ZFI is a collection of teaching strategies that go beyond current practice, but are feasible given the prevailing environment of the school in terms of its ability to foster and sustain innovation Rogan (2006:441). To make the argument practical: if a teacher does not set goals for his/her own learning in terms of facilitating inquiry learning in the school laboratory, it is unlikely that the teacher would progress to a higher level in the Rogan and Grayson's construct.

Due to time constraints during professional development interventions, it is not always possible for facilitators to address the individual needs of teachers. Instead, the SLP's set the stage for teachers to set their own learning goals for themselves, in terms of all four dimensions. A practical example from our research illustrates this point. During the African Centre for DNA Barcoding intervention, science teachers were exposed to advanced laboratory techniques related to Polymerase Chain Reaction (PCR). For many of the teachers, this was intricate work, of which they did not have a good understanding. This cognitive dissonance paved the way for them to set personal learning goals for themselves, e.g. learning more about PCR, or familiarising themselves with some of the unknown laboratory techniques. The proposed fifth dimension introduced in this paper sees self-directed learning as almost a sine qua non for the other four. Such a focus on SDL could arguably assist the teacher in a quicker transition from one level to the next as proposed in table 3 . 
TABLE 3: Profile of implementation of science teachers

\begin{tabular}{|c|c|c|c|c|c|}
\hline $\begin{array}{l}\# \\
L\end{array}$ & $\begin{array}{l}\text { Classroom } \\
\text { interaction }\end{array}$ & $\begin{array}{l}\text { Science practical } \\
\text { work }\end{array}$ & $\begin{array}{l}\text { Science in } \\
\text { society }\end{array}$ & Assessment & $\begin{array}{l}\text { Teachers Self- } \\
\text { Directed Learning** }\end{array}$ \\
\hline 0 & $\begin{array}{l}\text { Teacher presents } \\
\text { transmission-type } \\
\text { lesson in an } \\
\text { unstructured way } \\
\text { and reads mostly } \\
\text { from the textbook; } \\
\text { Limited and } \\
\text { ineffective media } \\
\text { usage; } \\
\text { Learners passive } \\
\text { and not engaged. }\end{array}$ & $\begin{array}{l}\text { Practical work is } \\
\text { seldom done; } \\
\text { Teacher uses } \\
\text { limited and not } \\
\text { well-planned } \\
\text { demonstrations to } \\
\text { assist in the } \\
\text { explanation of } \\
\text { concepts. }\end{array}$ & $\begin{array}{l}\text { Teacher seldom } \\
\text { uses examples } \\
\text { from the } \\
\text { learners' daily } \\
\text { lives, and if } \\
\text { used these are } \\
\text { incoherent. }\end{array}$ & $\begin{array}{l}\text { Written tests } \\
\text { on lower } \\
\text { cognitive } \\
\text { levels; } \\
\text { Tests marked } \\
\text { and handed } \\
\text { out to learners. }\end{array}$ & $\begin{array}{l}\text { There is no evidence } \\
\text { of SDL; the teacher } \\
\text { do not show interest } \\
\text { in ongoing } \\
\text { professional } \\
\text { activities. }\end{array}$ \\
\hline 1 & $\begin{array}{l}\text { Teacher presents } \\
\text { organised lessons; } \\
\text { Uses textbook } \\
\text { effectively; } \\
\text { Learners are } \\
\text { engaged and } \\
\text { respond to } \\
\text { questions. }\end{array}$ & $\begin{array}{l}\text { Teacher uses } \\
\text { classroom } \\
\text { demonstrations to } \\
\text { help develop } \\
\text { concepts. }\end{array}$ & $\begin{array}{l}\text { Teacher uses } \\
\text { examples from } \\
\text { everyday life to } \\
\text { illustrate } \\
\text { scientific } \\
\text { concepts. }\end{array}$ & $\begin{array}{l}\text { Written tests } \\
\text { are given; } \\
\text { Most questions } \\
\text { of recall type; } \\
\text { Most tests } \\
\text { marked and } \\
\text { returned } \\
\text { promptly. }\end{array}$ & $\begin{array}{l}\text { There is minimal } \\
\text { evidence of SDL; the } \\
\text { teacher indicates } \\
\text { that he/she has } \\
\text { professional } \\
\text { development needs, } \\
\text { but there are no } \\
\text { concrete learning } \\
\text { goals identified. }\end{array}$ \\
\hline 2 & $\begin{array}{l}\text { Textbook used along } \\
\text { with other resources; } \\
\text { Engages learners } \\
\text { with questions that } \\
\text { encourage deeper } \\
\text { thinking and } \\
\text { meaningful group } \\
\text { work. }\end{array}$ & $\begin{array}{l}\text { Teachers uses } \\
\text { demonstrations to } \\
\text { promote a limited } \\
\text { form of inquiry; } \\
\text { Learners } \\
\text { participate in } \\
\text { 'cookery book' } \\
\text { practical work. }\end{array}$ & $\begin{array}{l}\text { Teacher bases } \\
\text { lessons on } \\
\text { specific } \\
\text { problems faced } \\
\text { by community. }\end{array}$ & $\begin{array}{l}\text { Written tests } \\
\text { include } 50 \% \text { of } \\
\text { higher } \\
\text { cognitive level } \\
\text { questions. }\end{array}$ & $\begin{array}{l}\text { The teacher } \\
\text { formulated learning } \\
\text { goals, but there is } \\
\text { limited evidence that } \\
\text { learning resources } \\
\text { or learning } \\
\text { strategies were } \\
\text { identified. }\end{array}$ \\
\hline 3 & $\begin{array}{l}\text { Teacher structures } \\
\text { learning along 'best } \\
\text { practice' lines; } \\
\text { Learners engage in } \\
\text { minds-on learning } \\
\text { activities. }\end{array}$ & $\begin{array}{l}\text { Practical work to } \\
\text { encourage learner } \\
\text { discovery of } \\
\text { information. }\end{array}$ & $\begin{array}{l}\text { Learners } \\
\text { actively } \\
\text { investigate the } \\
\text { application of } \\
\text { science \& } \\
\text { technology in } \\
\text { their own } \\
\text { environment. }\end{array}$ & $\begin{array}{l}\text { Written tests } \\
\text { include 'guided } \\
\text { discovery'-type } \\
\text { activities; } \\
\text { Assessment } \\
\text { includes other } \\
\text { forms such as } \\
\text { reports. }\end{array}$ & $\begin{array}{l}\text { There is clear } \\
\text { evidence of SDL: } \\
\text { learning goals, } \\
\text { resources and } \\
\text { applicable strategies } \\
\text { were identified. } \\
\text { However, there is no } \\
\text { evidence of } \\
\text { evaluating the } \\
\text { learning actions. }\end{array}$ \\
\hline 4 & $\begin{array}{l}\text { Learners take major } \\
\text { responsibility for }\end{array}$ & $\begin{array}{l}\text { Learners design } \\
\text { and do open }\end{array}$ & $\begin{array}{l}\text { Learners } \\
\text { actively }\end{array}$ & $\begin{array}{l}\text { Open } \\
\text { investigations }\end{array}$ & $\begin{array}{l}\text { Strong evidence that } \\
\text { the teacher is a self- }\end{array}$ \\
\hline
\end{tabular}




\begin{tabular}{|c|c|c|c|c|}
\hline $\begin{array}{l}\text { own learning and } \\
\text { undertake long-term } \\
\text { investigations and } \\
\text { projects; } \\
\text { Teacher facilitates } \\
\text { learning. }\end{array}$ & investigations. & $\begin{array}{l}\text { undertake a } \\
\text { project in their } \\
\text { local community } \\
\text { and explore } \\
\text { long-term } \\
\text { effects of } \\
\text { community } \\
\text { projects. }\end{array}$ & $\begin{array}{l}\text { and } \\
\text { community- } \\
\text { based projects } \\
\text { included in } \\
\text { final } \\
\text { assessment; } \\
\text { Learners } \\
\text { create } \\
\text { portfolios. }\end{array}$ & $\begin{array}{l}\text { directed learner i.e. } \\
\text { the teacher can } \\
\text { define his or her own } \\
\text { goals, goals related } \\
\text { to central need, able } \\
\text { to set a path to } \\
\text { achieve the goal, } \\
\text { the goal is realistic } \\
\text { not too high or too } \\
\text { low, but enough to } \\
\text { be challenging, and } \\
\text { the teacher } \\
\text { evaluates whether } \\
\text { the learning goals } \\
\text { were achieved. } \\
\text { The teacher } \\
\text { promotes SDL in } \\
\text { his/her classroom. }\end{array}$ \\
\hline
\end{tabular}

Source: Rogan 2004b:159; taken from Petersen \& De Beer, 2016, p. 281 - 282 and revised by Sebotsa, De Beer \& Kriek, 2019. The latter authors suggest a stronger focus on Self-Directed Learning.

* Addition to the original Rogan (2004b:159) Profile of Implementation by Petersen (2011:246).

** Contribution of this paper to the original Profile of Implementation.

\#L denote Level in the above table

\section{Conclusion and recommendations}

In conclusion, we would like to highlight research done by Schulze and Van Heerden's (2015) on factors that motivate students to engage in science. Their research has shown that the science classroom is the most motivational factor. The teacher plays a pivotal role in creating such motivational spaces in their classrooms. To create such a learning space, requires teacher competence in terms of pedagogical content knowledge and communication skills, an understanding of the importance of practical (inquiry) learning, skills to contextualise science, and create authentic learning opportunities, and lastly, assessment methods that will further support student learning. The authors of this paper are of the view that the revised Rogan and Grayson heuristic will assist many facilitators in structuring interventions more effectively, by mainstreaming self-directed learning.

However, such development requires the teacher to be a self-directed learner. We argue that, by including this 5th dimension to the Profile of Implementation, it could serve as a constant reminder to teacher educators to make self-directed learning principles one of the design principles in their interventions. Self-directed learning speaks to all four other domains. In order to improve classroom interaction, develop practical work opportunities embedded in inquiry learning, clearly showing the science-and-society link, or engaging in innovative assessment, all require the teacher to, as a self-directed learner, (a) set personal learning goals for themselves; (b) identify resources to achieve these learning goals (that could include other people, e.g. the more 
knowledgeable other); (c) decide upon relevant learning strategies, and (d) monitor and evaluate their own learning (Knowles, 1975). The revised Rogan and Grayson heuristic will also guide teacher educators when designing and implementing teacher professional development interventions.

\section{References}

Abd-El-Khalick, F., Bell, R.L. and Lederman, N.G., 1998. The nature of science and instructional practice: Making the unnatural natural. Science education, 82(4), pp.417-436.

Bhorat, H., 2004. Labour market challenges in the post-apartheid South Africa. South African Journal of Economics, 72(5), pp.940-977.

Bourdieu, P., 1986. The force of law: Toward a sociology of the juridical field. Hastings LJ, 38, p.805.

Breault, D.A. and Marshall, J.D., 2010. Curriculum, definitions of. Encyclopedia of curriculum studies, 1, pp.179-181.

Cheng, S.F., Kuo, C.L., Lin, K.C. and Lee-Hsieh, J., 2010. Development and preliminary testing of a selfrating instrument to measure self-directed learning ability of nursing students. International journal of nursing studies, 47(9), pp.1152-1158.

Cooke, N.J. and Gorman, J.C., 2006. Assessment of team cognition. International encyclopedia of ergonomics and human factors, pp.270-275.

Cronje, A., 2015. Epistemological border-crossing between Western science and indigenous knowledge and its implications for teacher professional development (Unpublished PhD thesis). University of Johannesburg.

De Beer, J. and Ramnarain, U., 2012. The implementation of the FET Physical-and Life Sciences curricula: Opportunities and challenges. unpublished report prepared for the Gauteng Department of Education, UJ Library, University of Johannesburg.

De Beer, J., 2016. Re-imagining science education in South Africa: the affordances of indigenous knowledge for self-directed learning in the school curriculum. Journal for New Generation Sciences, 14(3), pp.34-53.

Dubinsky, J.M., Roehrig, G. and Varma, S., 2013. Infusing neuroscience into teacher professional development. Educational Researcher, 42(6), pp.317-329.

Festinger, L., 1962. A theory of cognitive dissonance (Vol. 2). Stanford university press.

Harrold, M., Agrawala, S., Steele, P., Sharma, A., Hirsch, D., Liptow, H., Sharma, M., Abeygunawardena, P., Foy, T., Debois, M. and Kashyap, A., 2002. Poverty and climate change: Reducing the vulnerability of the poor through adaptation.

Hiemstra, R. and Brockett, R.G., 2012. Reframing the meaning of self-directed learning: An updated modeltt.

Jackson, C., De Beer, J., \& White, L. 2018. The affective affordances of frugal science (using foldscopes) during a life sciences water quality practical. Proceedings of the $9^{\text {th }}$ ISTE Conference on Mathematics, Science and Technology Education, Kruger Park, 22 - 25 October 2018.

Jansen, J., 2017. Introduction-Part II. Decolonising the university curriculum given a dysfunctional school system?. Journal of Education (University of KwaZulu-Natal), (68), pp.4-13.

Jenkins, E.W., 1999. Practical work in school science. Practical work in science education: Recent research studies, pp.19-32. 
Knowles, M.S., 1975. Self-directed learning. The International Encyclopedia of Education (second edition), Oxford: Pergamon Press.

Kotoka, J. and Kriek, J., 2014. The impact of computer simulations as interactive demonstration tools on the performance of Grade 11 learners in electromagnetism. African Journal of Research in Mathematics, Science and Technology Education, 18(1), pp.100-110.

Kriek, J. and Grayson, D., 2009. A holistic professional development model for South African physical science teachers. South African journal of education, 29(2).

Many SA mathematics teachers know less than 11-year-old kids. (2017, June, 6). My Broadband. Retrieved :https://mybroadband.co.za/news/government/107804-many-sa-mathematics-teachers-know-lessthan-11-year-old-kids.html

Mentz, E. and De Beer, J., 2019, 'The use of Cultural-Historical Activity Theory in researching the affordances of indigenous knowledge for self-directed learning'. In: J. de Beer (Ed). The decolonization of the curriculum project: The affordances of indigenous knowledge for self-directed learning, Stellenbosch: AOSIS.

Motambatamba, L.A.L., 2018. Science teachers' views of the nature of science, and its implications for pedagogical content knowledge development (Doctoral dissertation, University of Johannesburg).

Mothwa, M.M., 2011. Teachers' experiences of incorporating indigenous knowledge in the life sciences classroom (Doctoral dissertation, University of Johannesburg).

Mullis, I.V., Martin, M.O., Foy, P. and Arora, A., 2012. TIMSS 2011 international results in mathematics. International Association for the Evaluation of Educational Achievement. Herengracht 487, Amsterdam, 1017 BT, The Netherlands.

Munroe, E., Borden, L., Murray Orr, A., Toney, D. and Meader, J., 2013. Decolonizing Aboriginal education in the 21st century. McGill Journal of Education/Revue des sciences de l'éducation de McGill, 48(2), pp.317-337.

Nakata, M., 2002. Indigenous knowledge and the cultural interface: Underlying issues at the intersection of knowledge and information systems. IFLA journal, 28(5-6), pp.281-291.

NEIMS., 2011. National Education Infrastructure Management System. May report.

Nwaneri, O. (2019, July, 2019). Youth need skills for the fourth industrial revolution. Mail \& Guardian. Retrieved from https://mg.co.za/article/2019-06-25-00-youth-need-skills-for-the-fourth-industrialrevolution

Odhiambo, N.M., 2015. Government expenditure and economic growth in South Africa: An empirical investigation. Atlantic Economic Journal, 43(3), pp.393-406.

Petersen, N.T. and De Beer, J.J., 2012. The professional development of life sciences teachers in an ecology of practice. Suid-Afrikaanse Tydskrif vir Natuurwetenskap en Tegnologie, 31(1), p.11.

Petersen, N.T., 2011. Onderrig en leer in die lewenswetenskappe-klaskamer en implikasies vir professionele ontwikkeling van onderwysers (Doctoral dissertation, University of Johannesburg).

Podolefsky, N.S., Rehn, D. and Perkins, K.K., 2013, January. Affordances of play for student agency and student-centered pedagogy. In AIP Conference Proceedings (Vol. 1513, No. 1, pp. 306-309). AIP.

Pretorius, E.D., 2015. Learning communities for the professional development of science teachers (Doctoral dissertation, University of Johannesburg).

Ramnarain, U. \& Schuster, D. (2014). The pedagogical orientations of South African Physical Sciences teachers towards inquiry or direct instructional approaches. Research in Science Education 44: 627 650. 
Rogan, J.M. and Grayson, D.J., 2003. Towards a theory of curriculum implementation with particular reference to science education in developing countries. International journal of science education, 25(10), pp.1171-1204.

Saldaña, J., 2015. The coding manual for qualitative researchers. Sage.

Samudram, M., Nair, M. and Vaithilingam, S., 2009. Keynes and Wagner on government expenditures and economic development: the case of a developing economy. Empirical Economics, 36(3), pp.697-712.

Savides, M (2017, June, 6). South African schools have 5,139 teachers who are unqualified or underqualified. Times Live. Retrieved from: https://www.timeslive.co.za/news/south-africa/2017-06-06south-african-schools-have-5139-teachers-who-are-unqualified-or-under-qualified/

Sawada, D., Piburn, M., Turley, J., Falconer, K., Benford, R., Bloom, I. and Judson, E., 2000. Reformed teaching observation protocol (RTOP) training guide. ACEPT IN-002. Arizona Board of Regents.

Sebotsa,T., De Beer,J., \& Kriek, J. 2018. Considerations for teacher professional development: A case study on a community of practice ("The A-team Teachers"). Proceedings of the $9^{\text {th }}$ ISTE Conference on Mathematics, Science and Technology Education, Kruger Park, 22 - 25 October 2018.

Schulze, S. and van Heeren, M., 2015. Learning environments matter: Identifying influences on the motivation to learn science. South African Journal of Education, 35(2), p.1058.

Spaull, N., 2015. Schooling in South Africa: How low-quality education becomes a poverty trap. South African Child Gauge, 12, pp.34-41.

Statistics South Africa., 2019. Youth graduate unemployment rate increases in Q1: 2019. Quarterly Labour Force Survey .

Taylor, D.L. and Cameron, A., 2016. Valuing IKS in successive South African physical sciences curricula. African Journal of Research in Mathematics, Science and Technology Education, 20(1), pp.35-44.

Taylor, N., Fleisch, B. and Shindler, J., 2019. Education scenarios for 2019. Key driving forces scenarios, pp.11-12.

This graph shows just how bad South Africa is at education. (2017, June, 4). BUISINESSTECK. Retrieved from:https://businesstech.co.za/news/government/89446/this-graph-shows-just-how-bad-southafrica-is-at-education/

Van Wyk, B.E. and Gericke, N., 2000. People's plants: a guide to useful plants of Southern Africa. Briza Publications.

White, L., and De Beer, J. 2017. A leap too far: An evaluation of Life Sciences teachers' learning during a three-day short learning programme on indigenous knowledge. Proceedings of the $8^{\text {th }}$ ISTE Conference on Mathematics, Science and Technology Education, Kruger Park, 23 - 26 October 2017.

World Bank., 2014. Overcoming Poverty and Inequality in South Africa: An Assessment of Drivers, Constraints and Opportunities.

Zakaria, E. and Iksan, Z., 2007. Promoting Cooperative Learning in Science and Mathematics Education: A Malaysian Perspective. Online Submission, 3(1), pp.35-39.

Zinyeka, G., Onwu, G.O. and Braun, M., 2016. A truth-based epistemological framework for supporting teachers in integrating indigenous knowledge into science teaching. African Journal of Research in Mathematics, Science and Technology Education, 20(3), pp.256-266. 